\title{
The influence of service quality, product quality, and lifestyle on repurchase intention mediated by customer satisfaction at Starbucks in Surabaya
}

\author{
D.A. Dwiyanty \& Ronny \\ STIE Perbanas Surabaya, Indonesia
}

\begin{abstract}
The development of the food and beverage business in the modern era is so rapid that it is not surprising to find coffee shops on many streets or in malls. Starbucks is a modern coffee shop that can often be found in malls and is spread across Indonesia. As a popular coffee shop, Starbucks needs to provide the best services and products for its consumers to maintain its existence.
\end{abstract}

\section{INTRODUCTION}

\subsection{Background}

Starbucks is one of the modern coffee shops that can often be found in malls and is spread across Indonesia. Starbucks is popular with the general public, as seen from the many consumers who visit Starbucks for buying coffee or for just hanging out. Starbucks visitors are predominantly students; they do their assignments and hang out with their friends at the place.

Customer repurchase intention is a stage where the choice of brand is formed. High repurchase intention reflects a high level of consumer satisfaction when deciding to choose a product. This is also affected by the quality of service.

In this study, service quality indicates a measure of the service level provided by Starbucks in fulfilling customer expectations. Customer satisfaction after purchase is highly dependent on offering performance in relation to consumer expectations. However, in Indonesia, the society and technological advances have a tendency to change people's lifestyles and perspectives, especially in the urban society with a modern lifestyle.

\section{METHODOLOGY}

The population in this study is Starbucks' customers. The sample of 100 respondents was taken by a non-probability sampling technique using the purposive sampling method. The primary data source was used in this study. Variables in this study included independent variables, namely, quality of service, quality of product, and lifestyle, and a dependent variable, namely, repurchase intention.

\subsection{Data analysis technique}

This study took measurements to obtain the mode and average value of respondents' responses. The mode was used to create different groups of subjects or simply to determine the characteristics 
of the respondents. This study employed a partial least squares structural equation modeling (PLSSEM) as a test tool to find out if there is a relationship between variables in a linear and nonlinear relationship and various indicators.

\section{DISCUSSION}

Quality of service is a customer perception after purchasing the related service (Demir \& Aydinli, 2016). The service quality level depends significantly on consumer acceptance of the services provided in relation to their expectations. The need for a good relationship between Starbucks and its customers creates an opportunity for Starbucks to know and understand the needs and expectations of its customers. Therefore, Starbucks can provide good quality products for customers with satisfaction and create pleasant experiences and minimize experiences that tend to disappoint customers in using the product. Kotler and Armstrong (2016:11) state that product quality includes factors such as durability, reliability, accuracy, ease of operation, repair of product, and other attributes.

Nowadays, the customers tend to pay more attention to service details. In the event of a service failure, customers generally stop buying the product and spread the word to their closest people, which is detrimental to the company. Therefore, handling service failures needs to be a priority for business owners (Kumar et al., 2016). According to Sumarwan (2003), lifestyle is defined as the people's behavior on how to live, spend money, and take advantage of their time. Currently, there is a tendency in the Indonesian society to adapt a modern lifestyle; they do that by choosing, for example, a modern coffee shop such as Starbucks.

After customers make a purchase of services and products, they will evaluate whether the services and products fulfilled their expectations. This phase is known as post-purchase or post-consumption evaluation. The post-consumption evaluation of the Starbucks products will include whether or not consumers were happy with the products that they had consumed. According to Tjiptono (2012), customer satisfaction is when they realize that their needs and desires are well fulfilled. If the performance of the services and products exceeds their expectations, consumers will be satisfied; therefore, repurchase intention can occur.

Repurchase intention is a post-purchase action that is due to the consumer's satisfaction with the purchased product. Repurchase intention has two forms, namely, the intention to make a repurchase and the intention to recommend it to the closest person (Hilal and Top, 2019).

\section{CONCLUSION}

Based on the aforementioned discussion, if the service quality is good and the product quality is in line with expectations, then the consumers' repurchase intention level is higher. Also, if a person's lifestyle reflected in the purchased product is in line with expectations, the consumers' repurchase intention level is higher. This can occur because of customer satisfaction, which can affect repurchase intentions. In other words, customers' repurchase intention can increase in accordance with their satisfaction, that is, their experience obtained from the quality of the service provided, the quality of the product received, and the suitability of their lifestyle.

\section{REFERENCES}

Demir, A., \& Aydinli, C. 2016. Exploring the Quality Dimensions of Mobile Instant Messaging Applications and Effects of Them on Customer Satisfaction. International Journal of Computer Theory and Applications, $9(22), 1-15$.

Hilal, D. \& Top, C. 2019. Impact of Product and Service Quality of Gated Communities on the Purchasing Intentions: Case Study in Kurdistan Region of Irak. International Journal of Economics, Commerce and Management. 7(6). 
Ibzan, E., Balarabe, F., \& Jakada, B. 2016. Consumer Satisfaction and Repurchase Intentions. Developing Country Studies. 6(2), 96-100.

Tarofder, A. K., Nikhashemi, S. R., Azam, S. M. F., Selvantharan, P., \& Haque, A. 2016. The Mediating Influence of Service Failure Explanation on Customer Repurchase Intention through Customers Satisfaction. International Journal of Quality and Service Sciences. 8(4), 516-535.

Kotler, P., and G. Amstrong. 2016. Prinsip-prinsip Pemasaran [13th Ed.]. Jakarta: Erlangga.

Sumarwan, U. 2003. Perilaku Konsumen. Jakarta: Galia Indonesia.

Tjiptono, F. \& Chandra G. 2012. Pemasaran Strategik. Yogyakarta: Andi. 